\title{
THE GEOSTRATEGY OF SHARIA BANKING MERGER IN INDONESIA
}

\author{
Agus Hartanto \\ School of Strategic and Global Studies, \\ Universitas Indonesia, \\ Jakarta, Indonesia \\ agus.hartanto@ui.ac.id \\ Nur Fatwa \\ Department of European Studies, School of Strategic and Global Studies, \\ Universitas Indonesia, \\ Jakarta, Indonesia \\ nurfatwa@ui.ac.id
}

DOI: $10.31364 /$ SCIRJ/V8.i12.2020.P1220829

http://dx.doi.org/10.31364/SCIRJ/v8.i12.2020.P1220829

\begin{abstract}
The merger of three Sharia Commercial Banks (Namely BUS) subsidiaries of State-Owned Enterprises (BUMN) to become the largest Sharia Commercial Bank in 2021 is the government's commitment to advancing Islamic finance as a new pillar of national economic strength. A critical analysis is carried out to obtain the merger action's meaning using internal and external geostrategic studies. The analysis shows that now is the right time to do the merger option. This merger has a strategic role in realizing Indonesia's vision as a center for Islamic finance in the world. Indonesian capital resources such as members of the G-20, integration of AEC 2020, demographic bonus, credit to GDP ratio in Indonesia, level of public literacy, government commitment, demographics of Islamic bank employees, shared vision of Islamic banking stakeholders, the success of SMEs in the financing, are the sources of capital to increase the Islamic financial ecosystem. The merged bank will have a strong base capital to expand and obtain longterm funding sources nationally and globally. The competitive advantage of participating banks will present various banking products and services that can compete with other national banks to boost economic development.
\end{abstract}

Index Terms: Merger, Geostrategic, Islamic Bank, Islamic Finance, Vision.

\section{INTRODUCTION}

The merger of three Islamic commercial banks, stateowned companies, answered the long wait to form the largest national Islamic commercial bank with strong capital. The merger design document explains that this merger has a vision of achieving national Islamic banking to become one of the 10 largest Islamic banks based on global market capitalization within the next 5 years (BNIS, 2020). This is in line with the vision of the 2019-2024 Indonesian Sharia Economic Master Plan, making Indonesia an independent, prosperous, and civilized country by becoming the world's leading sharia economic center (Bappenas, 2018). Islamic banks have an important role in the banking industry in Indonesia (Fatwa, 2017, 2020).
PT Bank BRI Syariah Tbk signed the conditional merger agreement (CMA). (BRIS), PT Bank BNI Syariah (BNIS), and PT Bank Syariah Mandiri (BSM) on October 12, 2020 (BNI, 2020). The CMA is the first step, then a Project Management Office (PMO) Team takes the technical steps of the merger process. The Indonesian government targets that on February 1, 2021, a newly merged entity will be formed (BNIS, 2020).

The new entity shareholder is PT Bank Mandiri Persero (BMRI) Tbk as the parent company of BSM, which is the equivalent of 51.2 percent. The remaining shares are divided, namely PT Bank Negara Indonesia Persero (BBNI) Tbk as the parent company of BNIS by 25 percent, PT Bank Rakyat Indonesia Persero (BBRI) Tbk as the holding company of BRIS by 17.4 percent, DPLK BRI-Sharia shares of 2. Percent, PT BNI Life Insurance and PT Mandiri Sekuritas (under 1 percent), and public shares of 4.4 percent (BNIS, 2020). BRIS becomes the holder of the bank holding entity that receives this merger or the surviving entity. Meanwhile, BSM and BNIS are merged banks (BNIS, 2020).

Referring to the data on the financial statements of Islamic banks participating in the merger for the position of September 2020, BSM assets are IDR 114.3 Trillion (BSM, 2020), BNIS assets IDR 50.7 Trillion (BNIS, 2020), and BRIS assets IDR 49.5 Trillion (BRIS, 2020), the total new entities combined will be IDR 214.6 trillion. The accumulated assets resulting from this merger will place the new entity's Islamic bank into the 7th largest national bank in Indonesia. This merger also led to a new entity, sharia bank, having a total capital of Rp. 20.4 trillion so that it was included in the category Book Bank III, a class of banks whose core capital is between Rp. 5 trillion to Rp. 30 trillion (BI, 2012).

This paper aims to conduct a critical analysis of this merger activity regarding Indonesia's Islamic banking geostrategy. Internal analysis is more focused on the situation of national Islamic banking and merger-participating banks. Meanwhile, external analysis emphasizes the global situation and opportunities to be achieved after the merger. By conducting critical analysis, it is hoped that the output can fill the gap in the study of the merger of national Islamic banking in Indonesia. 


\section{LITERATURE REVIEW}

Strategy to be used as a general form of a plan, concept, action, or vision of a direction carried out by individuals, organizations, and governments, whether at the regional, state, or state level (Yarger, 2006). Strategies at all levels are objective calculations, concepts, and resources for an acceptable risk to create the desired goals (Yarger, 2006). The National Resilience Institute (Namely lemhanas) states geostrategy is a strategy in utilizing the system's geographic conditions in determining policies, objectives, and means to realize the ideals of the proclamation and national goals. Indonesia's geostrategy is manifested through the concept of national resilience that grows in the embodiment of ideological, political, economic, socio-cultural, and defense and security unity (Mulyono, 2017).

Frederic Pryor (1985) defines a sharia economic system as a theoretical construction of an industrial economic system, the perpetrators of which follow Islamic teachings. This understanding is reinforced by the Global Islamic Economic Report (GIER 2013), which defines the Islamic economy as all the core sectors of the economy and their ecosystems that are structurally influenced by consumer lifestyles and business practices according to Islamic values (Bappenas, 2018). Robert M. Gates explained that the pillars of a strong state are military and diplomacy, economy, communication strategy, development assistance, intelligence, technology, ideology, and cyber (Gates, 2020). Economy, as an element of stability, requires precision in determining strategy. This is also a response to globalization and the interests of research on forming new economic orders (Gaiduchok, 2019). The results of the Ernst \& Young (EY) survey on Geostrategy in Practice 2020 show that companies must be more serious in implementing geostrategy, namely incorporating political risk management into corporate risk management, strategy, and corporate governance more deeply (Cline \& McCaffrey, 2020).

The merger option is a conceptual framework and strategy in responding to organizations in the same and interconnected ecosystem (Pfeffer, 1972). Empirical studies show that most mergers will improve company operations to be more efficient, and product prices are lower (DePamphilis, 2014). Cultural integration is very crucial and complicated in mergers and acquisitions. There is often a cultural clash when the integration process begins (Moin, 2010). Mergers and acquisitions of companies will have a drastic impact on the lives of individual employees and organizations. This effect is called merger syndrome, which impacts cultural changes, performance appraisals, resistance to change, insecurities about losing a job, and other fears (Cartwright \& Cooper, 1996).

\section{RESEARCH METHODS}

The research method uses descriptive qualitative methods. Literature studies are carried out by conducting critical studies from scientific journals, books, opinions, and report documents that support the research theme. The problem is approached with a critical analysis framework to get meaning from the merger process. Regional analysis is divided into two, internal and external geostrategy. It is hoped that this critical analysis will achieve corroborating results that will be carried out.

\section{RESULTS AND DISCUSSION}

\section{A. Internal Geostrategic Analysis}

The journey of Islamic banking in Indonesia began with PT Bank Muamalat Indonesia (Namely BMI) in 1992. BMI came from The main idea of Islamic religious figures for the development of Islamic banking in Indonesia. In the same year, the government also enacted Act Number 7 of 1992 concerning banking, which then followed Government Regulation Number 72 of 1992 concerning Banks Based on the Profit Sharing Principle. During the period 1992 - 1998, Islamic banking did not show significant progress. This is due to the absence of market instruments and alternative liquidity management. The existence of Syariah bank has not received optimal attention from the banking authority, especially in the provision of banking facilities, both within the framework of open market operations (open market operations), discount windows (discount windows), and bank credit facilities by Islamic principles (Nizar, 2016). Law Number 10 of 1998 supports the development of the Islamic banking industry in Indonesia, with the result that appeared Islamic banks in Indonesia, Bank Syariah Mandiri.

The central bank and financial services authority made several efforts to support the development of Indonesian Islamic banking. Some of the steps in question are making the 2002-2012 Indonesian Sharia Banking Development Blueprint in September 2002 by Bank Indonesia, making the 2015-2019 Indonesian Sharia Banking Roadmap by the Financial Services Authority (OJK) in June 2015. The Ministry of National Development Planning/Bappenas supports Syariah banking by creating and protecting the Sharia Financial Action Master Plan (MAKSI) on 2-4 August 2016 at the World Islamic Economic Forum (WIEF). The central bank prepared the Sharia Economic and Financial Blueprint Framework initiated by Bank Indonesia on 6 June 2017. It formed the National Sharia Finance Committee (Namely KNKS) on November 8, 2016, as a mandate of the National Committee for Sharia Economics and Finance (Namely KNEKS).

On February 10, 2020, KNEKS which accelerates, expands and advances the development of sharia economy and finance to support national economic resilience by establishing the International Islamic University of Indonesia (UIII), which has a vision of helping to create a better world through the best graduates in education and research on Islam and Muslims in the world, which will begin to be built in 2018. The Indonesian Sharia Economics Master Plan 2019 - 2024 in May 2019 support the merger of a national sharia bank, a state-owned subsidiary, by signing a Conditional Merger Agreement (CMA) on October 12, 2020, which is in line with the target that the new National Sharia Bank, a state-owned subsidiary, will be formed on February 1, 2021.

The merger design document states, the bank merger results from the financial side will have sufficient capital and assets, human resources, information technology systems, or products to meet customer needs by sharia principles. This is expected to increase the bank sharia assets and increase competitiveness. The bank merger results are expected to compete globally with the 10 largest Islamic banks in the world (BNIS, 2020).

This merger plan scenario has been heard since 2014. In fact, several institutions have made studies on Islamic bank mergers. The Fiscal Policy Agency (BKF) of the Ministry of Finance of the Republic of Indonesia in November 2016 
recommend a merger between Syariah banking Commercial Bank. New Islamic banks are positioned as champion banks, while the other three banks are dissolved (Nizar, 2016). The KNEKS in July 2019 supports the scenario for planning largescale Islamic banks through several options. The option is to convert state-owned or private conventional banks, merging state-owned Islamic banks (Namely BUMN) and parent-owned Islamic banks BUMN, to establish a new Sharia BUMN bank or strengthening one of the existing BUMN-owned Islamic banks (KNEKS, 2019). The government finally chose to merge three Islamic Public Bank subsidiaries of BUMN to become a new entity.

Islamic banking assets' growth is expected to grow rapidly until 2023. This is by OJK regulations, which require the Sharia Business Unit (UUS) to spin-off from its group to become a new Sharia Commercial Bank (BUS) in a maximum of 2023. A BUS's formation can occur in a process - a spin-off from its parent or through acquisitions and mergers. The Aceh Qanun regional regulation, which requires all financial services in Aceh to be carried out by sharia, also encourages the acceleration of national Islamic banking assets' growth. OJK requires Syariah bank core capital until 2022 to be at least IDR 3 trillion.

Karim Consulting Indonesia projects that towards 2023 four scenarios will enrich the Islamic financial ecosystem. First, institutions whose social security will offer sharia services in 2021. Second, institutions with a focus on housing loans also offering savings sharia services. Third, sharia fintech will be at the forefront of customer acquisition through digital. Institutions responsible for hajj finance will stand out as large fund managers when liquidity is difficult during a pandemic (Karim, 2020).

The penetration rate of Islamic bank assets in Indonesia as of June 2020 was $6.18 \%$ compared to conventional banking assets classified as low (OJK, 2020). The growth of Islamic bank financing and third-party funds has increased higher in the last 5 years than conventional banks' growth, which has grown between $12-14 \%$ per year (OJK, 2020). Compared with the penetration of sharia assets in countries with a high Muslim population such as Malaysia, Brunei, Kuwait, Bahrain, and Saudi Arabia, in 2019, the average was above 20\%. Some even reached above 50\%; it is very far (BNIS, 2020). The growth of sharia banking assets generated from the sharia banking industry can be seen in the table below.

Table 1. Main Indicators of Islamic Banking

\begin{tabular}{|l|c|c|c|c|c|}
\hline Banking Industry & $\begin{array}{c}\text { Number of } \\
\text { Institutions } \\
\text { (in trillion } \\
\text { rupiahs) }\end{array}$ & $\begin{array}{l}\text { Number } \\
\text { of Asset } \\
\text { Offices }\end{array}$ & $\begin{array}{c}\text { Asset } \\
\text { (in trillion } \\
\text { rupiahs) }\end{array}$ & $\begin{array}{c}\text { Financing } \\
\text { (in trillion } \\
\text { rupiahs) }\end{array}$ & $\begin{array}{c}\text { Third-party } \\
\text { funds (in } \\
\text { trillion } \\
\text { rupiahs) }\end{array}$ \\
\hline $\begin{array}{l}\text { Sharia } \\
\text { Commercial Bank }\end{array}$ & 14 & 1.942 & 356,33 & 232,86 & 293,37 \\
\hline $\begin{array}{l}\text { Sharia Business } \\
\text { Unit }\end{array}$ & 20 & 390 & 175,45 & 134,16 & 127,95 \\
\hline Rural bank & 162 & 626 & 13,61 & 10,50 & 8,89 \\
\hline \multicolumn{1}{|c|}{ TOTAL } & 196 & 2.958 & 545,39 & 377,53 & 430,21 \\
\hline
\end{tabular}

Source: Indonesian Sharia Banking Snapshot: Position June 2020, OJK.

\section{b. External Geostrategy Analysis}

Ernest \& Young's survey results to corporate leaders in the world show that three global issues will have a major impact on the business world in the next five years, namely: the role of the United States in the international system, the stability of Europe after Brexit, and the relationship between the United States and China (Cline \& McCaffrey, 2020). This development also affected the decline in capital flows to developing countries and resulted in continued pressure on currencies in various countries, including Indonesia (BNIS, 2020). The World Bank calls the 2016-2017 period a fragile recovery phase after the world economy experienced a long slowdown since the 2008/2009 crisis. A.T. Kearney called the world economic recovery in 2012 a "delicate recovery" because economic growth tends to be flat (KNEKS, 2019).

The Covid-19 pandemic is a global public health crisis, even as a political risk on a global scale. Political risks occur because governments across countries change domestic regulations drastically in response to the Covid-19 pandemic, impacting the business world (Cline \& McCaffrey, 2020). IMF data per October 2020 shows real GDP growth of minus $4.4 \%$, developing countries minus $3.3 \%$, and Indonesia is still slightly better at minus $1.5 \%$. The world GDP growth trend of minus $4.4 \%$ is the lowest since 1980 (IMF, 2020). The challenges of the world economy are increasingly complex and varied. The World Bank projects that the Covid-19 pandemic could make global economic growth this year, minus 5.2\% of Gross Domestic Product (GDP). This global recession is the worst since the second world war and is almost three times deeper than the global recession in 2009 (Dinar Standard, 2020).

Although world economic growth tends to be flat, Islamic economics and finance show the latest trends in two decades, both globally and nationally. The ranking of Indonesia's sharia economic development towards the world sharia economy shows an improving trend. The Global Islamic Economic Indicator (GIEI) 2020/2021 noted that Indonesia is in 4th place, up from 10th position in 2018/2019 (Dinar Standard, 2020). Malaysia is ranked first, second by Saudi Arabia, and third by the United Arab Emirates. With a Muslim population of 16.3 million, Malaysia is at the forefront of the economic development of halal food, sharia finance, travel, and pharmaceutical and cosmetic products.

The Islamic Finance Development Indicator (IFDI) report in 2019 placed Indonesia in 4th place, up from 10th in 2018. Assessment includes quantitative growth, knowledge, governance, awareness, and corporate social responsibility (CSR). The first rank is Malaysia, second by Bahrain, and third by the United Arab Emirates (IFDI, 2019). The 2019 Global Islamic Finance Report (GIFR) placed Indonesia in the global Islamic financial market with 81.93 , beating Malaysia with a score of 81.05 . Since 2011 the first rank has been occupied by Malaysia. GIFR's assessment on regulatory developments enhanced by the improvement of the Islamic banking and financial industry ecosystem, strong political support from the government, and the great potential offered by the Islamic economy (GIFR, 2019).

The State of the Global Islamic Economy Report (GIER) 2019/2020 reports that Muslims in the world, with a total of 1.9 billion people, spend USD 2.02 trillion in 2019 on the sectors of halal food, Islamic finance, travel, Muslim fashion, pharmacy and cosmetics, media and recreation. This growth rate reflects a growth of $3.2 \%$ y.o.y. since 2018. Also, Islamic financial assets are estimated to have reached USD 2.88 trillion in 2019. The Covid-19 pandemic is predicted to cause an $8 \%$ decline in global Muslim spending in 2020 for the halal food economy sector, Islamic finance., travel, Muslim fashion, pharmacy and cosmetics, media and recreation. However, all sectors of the economy, except travel, are expected to return to pre-pandemic levels of spending at the end of 2021. Muslim 
spending is projected to reach USD 2.3 trillion in 2024 at an annual cumulative growth rate (CAGR) of $3.1 \%$ (Dinar Standard, 2020).

The Islamic finance industry recorded an increase in global assets of $13.9 \%$ in 2019 , reaching USD2.88 trillion from the previous USD2.52 trillion in 2018. The three countries with the largest Islamic financial portfolio are Iran amounting to USD698.2 billion, Saudi Arabia at USD629, 4 billion, and Malaysia amounting to USD570, 5 billion. Indonesia itself is in seventh place with assets of USD99.2 billion. GIER projects that there will be no growth in global Islamic financial assets in 2020, and it is projected that assets will reach USD3.69 trillion in 2024 (Dinar Standard, 2020).

\section{c. Sharia Banking Merger}

The Minister for National Development Planning / Head of Bappenas stated there are trade, financial, and geopolitical risks, placing countries at risk of instability and vulnerability. In the absence of external uncertainty, opportunities, and transformation are the keys to the national economy (Bappenas, 2018). Considering and analyzing the global conditions above, combining the three BUS subsidiaries of this BUMN has found the right and strategic momentum. Indonesia must plan and execute the global sharia economic spending market of USD2.02 trillion properly and is targeted to increase after the Covid-19 pandemic era. This is a promising opportunity to move the national economy. Sharia bank financing products and services to the real sector, especially the more massive halal economic sector, are needed, both on a corporate scale (wholesale), commercial, consumer, and MSMEs.

The vision of making Indonesia be the leading sharia economy in the world is realistic in terms of geostrategy. Indonesia has strong capital resources. Indonesia is part of the global community, and the only country in Southeast Asia included in the group of G-20 member countries. This group collects almost $90 \%$ of the world's gross national product (GNP, GNP), 80\% of total world trade, and two-thirds of its population. This means that Indonesia contributes greatly to world gross domestic product (GDP) orders. Participating in the G-20 forum has made Indonesia have to create international standards and commitments, which remain invincible with national resilience.

The Asean Economic Community (MEA) began in 2015 and integrated into the financial sector in 2020. AEC was formed based on four pillars, making ASEAN a single market and production center, creating balanced economic growth, becoming a competitive economic area, and integrating into the global economy. The main points that characterize this AEC's existence are a very competitive economic area with an evenly distributed economic development area. The regions will be fully integrated into the global economy, and the last is a single production base and market. With the AEC enactment, all ASEAN member countries must merge their territorial boundaries in a free market; markets throughout ASEAN members will unite and become a single market (Muchsin, 2020).

Indonesia also has an increasing demographic bonus. Of the total 50 countries with a Muslim population globally, Indonesia is the largest Muslim country in the world. The total Muslim population reaches 229 million people, or $13 \%$ of the world's total Muslim population (Pew Research Center, 2020). When compared to countries that have developed Islamic finance, such as Malaysia with 16.3 million people, Saudi Arabia 31.8 million people, and the United Arab Emirates 4.6 million people, Qatar 1.5 million people, and Bahrain 1 million people, bonus Indonesia's demographics are a market opportunity that can drive the enormous real sector. This differentiates Indonesia from other countries. Banking with the real sector, both consumption, and investment as the driving force of the economy, is a fundamental factor in the Indonesian economy's stability, unlike the Islamic finance in Malaysia or Middle Eastern countries that place portfolios in capital market instruments.

Indonesia's credit to GDP ratio in the fourth quarter of 2019 was still at $35.7 \%$ or still below $50 \%$, so there is a huge potential for financing growth. In contrast to Malaysia and Singapore, which have reached $100 \%$. Therefore, the merged Islamic bank with large capital will be more flexible to finance the corporate, commercial, consumer, and MSME sectors. The new entity Islamic bank will be able to compete with other national banks, and with strong capital, it will be more attractive to obtain through Sukuk. Funding needs for environmentally friendly basic infrastructure (green projects) require great assistance. Merged Islamic banks can finance the National Strategic Project (PSN) originating from the Sukuk publication. Indonesia has become a leader in the publication of green Sukuk (green bonds) globally. In 2018, the US \$ 1.25 billion will be distributed exclusively for environmentally friendly projects under the Green Framework. However, the issuance of Sukuk compared to conventional debt securities in Indonesia was still below 5\% as of April 2020. In other Muslim countries such as Malaysia, Saudi Arabia, and the United Arab Emirates, the issuance of Sukuk compared to conventional bonds had an average of more than $20 \%$ as of April 2020 (BNIS, 2020).

The level of public literacy is low, $22 \%$ of the Indonesian population understands banking, and $57 \%$ of the population already use banking services (DPS OJK, 2015). This means that there is still a wide opportunity for product and service innovation in Islamic banks to attract people to take advantage of banking services. The support, and commitment of the Government of Indonesia to develop the sharia economic ecosystem. The government has carried out various strategic initiatives such as the establishment of BPKH, KNEKS, the publication of Green Sukuk globally, Cash WaqfLink Sukuk, Sharia national financial literacy program, availability of Halal Product Guarantee Law, Sharia Banking Law, Waqf Law, SBSN Law, Sharia Banking Roadmap, Master Plan Sharia Architecture, and the Master Plan for Sharia Economics.

The demographics of Islamic bank employees participating in the merger are still productive. Data on banks participating in the merger shows a weighted average of $78 \%$ of employees aged less than 40 years, a very productive age for work. This productive age is easier to accept changes, changes in change, and is attracted to new challenges. The total number of employees of the three banks participating in the merger in 2018 was 18,313 employees, of which $85 \%$ were undergraduate graduates. The same spirit wants to raise Islamic banking, which has universal values and sharia principles. The Islamic banking community has eagerly awaited the momentum of this Islamic bank merger. Sharia banking stakeholders realize that the security so far for greater development is limited capital. Banks in Indonesia are 
successful in financing MSMEs. These best practices provide capital for Islamic banking in strategic areas to expand to the global level. The fundamentals of banks in Indonesia are to finance the real sector, and the market is still wide open.

The merger of the three national Islamic bank subsidiaries of BUMN has the right momentum. It has strategic meaning to make Indonesia's vision the center of the world's sharia economy and finance. The advantages of this merger are that the merged Islamic bank assets are getting bigger and stronger. The merger proves that Islamic banks have a niche market for the Islamic economy that is still wide open. It can be more efficient in operations, financing, fundraising, and technology. Moreover, Syariah banking will have a complete range of products, ranging from corporate, commercial, consumer, and MSMEs with various reliable products and services. The merger is an effort and commitment to the development of the sharia economic ecosystem and a new pillar of national economic strength that encourages Indonesia to become the center of the global Islamic economy and finance, and it will have a major impact on the progress of the halal industry ecosystem in Indonesia. An extensive network will facilitate access for all community people to obtain financial services by sharia principles.

The new entity as the largest Islamic Commercial Bank in Indonesia is not a threat to Islamic Commercial Banks (BUS) or other Sharia Business Units (UUS) in Indonesia. But it will give a push to interesting competition in the national sharia economic ecosystem. Financial Services Authority (OJK) regulations that encourage the spin-off of UUS from its parent until 2023 and the minimum core capital requirement of IDR 3 trillion in 2022 will encourage the merger and acquisition process of Islamic banks to be more vibrant going forward to reach a new balance point.

National Islamic banking assets will not increase at the merger time unless additional paid-in capital is made. In fact, the number of Islamic Commercial Banks (BUS) after the merger will decrease from 14 BUS to 12 BUS. A significant addition occurred in the new entity's capital, which amounted to IDR 20.4 trillion and was included in the category of Book Bank III. The new entity will have Rp214.6 trillion in assets, control $40 \%$ of national Islamic banking assets, and rank 7 th in national banking, ahead of Bank Danamon and Maybank Indonesia (Supriyanto, 2020). Vice President Ma'ruf Amin, when speaking at a seminar on Sunday, October 25, 2020, expressed his optimism that the merged Islamic bank will have the capacity to develop assets of up to IDR 350 trillion by 2025 (Fauzan, 2020). In 2019, the largest asset of global Islamic banking by Al Rajhi Bank from Saudi Arabia with assets of 1,410 trillion, and the assets of this merger of Islamic banks will place 19th globally (Asian Banker, 2020).

As a comparison, two Islamic banks in Malaysia that have expanded overseas, namely CIMB Islamic, have assets as of June 2020 amounting to IDR 477 trillion (CIMB, 2020), while Maybank Islamic as of June 2020 has assets of IDR 869 trillion (Maybank, 2020). The CIMB Islamic entity is a subsidiary of CIMB Berhad. Likewise, Maybank Islamic is a subsidiary of Maybank Berhad. The parent company's advantages and expertise, especially in assessing financing risk management, serve as a guide for the subsidiary in running its business. Maybank and CIMB have carried out this best practice as the parent company in monitoring the risk of its global portfolio. The bank will also have an actual economic database of the bank's internal channels from various countries for economic strategy.

The competitive advantage inherent in each merger participating bank will strengthen the advantages of the new entity. BSM, as the largest Islamic bank, has a good technology system and procedures. BSM financing mostly targets the commercial and corporate business segments. Syndications to finance basic infrastructure projects by Islamic banks are often led by BSM. Likewise, BSM has often been involved in syndicating with large-scale conventional banks to take a portion of sharia financing. BNIS excels in digital banking services product innovations such as digital technology-based services, including filling out online forms for opening accounts through Hasanah Online, managing school finances with the Smart School Platform (PSP), and the only electronic money in Islamic banking, HasanahKu. Financing in the commercial sector has been an attractive segment financed by BNIS. Meanwhile, BRIS imitates the segment taken by its parent BRI, which is targeting the retail segment. BRIS has a well-mastered understanding of the characteristics of local and regional retail customers.

As Brett King stated in Bank 4.0, the digital era will change bank and customer behavior, banking activities without a physical presence, real-time, and artificial intelligence (King, 2018). Technology will be a challenge in this BUS merger process. After the merger date, the Core Banking System to be used comes from one of the merger participating banks. Portfolios from other merger participating banks will be migrated into the system owned by one of the merged participating banks (BNIS, 2020). Adaptation systems require time and high precautionary principles. As part of the procedure, the backup system is the main thing so that there is no risk of system failure, which will impact the three BUSs. Merger in this aspect of information technology is expected to provide the best, more efficient service due to decreased operating expenses. This digital banking era allows bank mergers to collaborate with fintech, e-commerce, and onlinebased inter-service companies to grow the market.

The bank merger results are also in line with the government's efforts to create a halal ecosystem, where the existence of a large scale. Islamic bank will be an important pillar in the success of the integration of Islamic finance in Indonesia (BNIS, 2020). Many conventional banks have supported the halal industry because of a wider range and product flexibility. The potential for the halal industry is enormous. The existence of a large and strong Islamic bank in liquidity will help access funds from 4.12 million Small and Medium Enterprises (MSMEs) that are legal entities (BPS, 2020). Moreover, the network infrastructure of more than 1,200 merged bank offices throughout Indonesia will make it easier for people to conduct transactions. The halal industry, as part of the sharia economic ecosystem, supports the national economy. It plays an important role in realizing the nation's aspirations as a just, prosperous, and sovereign country (Bappenas, 2018). In fact, the effect that appears is monitoring one sub-ecosystem and many other sub-ecosystems. The sharia economic ecosystem in Indonesia can be the main support for national economic development.

Clash culture or syndrome merger from this merger activity will reduce Islamic banking stakeholders' vision, namely the desire to raise Islamic banks, the boundaries of universal values and sharia principles, and still in the same environment, 
namely BUMN subsidiaries. The feeling of pride in working and being a professional in the largest Islamic bank will increase, increasing work productivity. Working in an Islamic bank is no longer a second-class citizen in the banking industry because it is clear that Islamic banks' assets are already ranked 7 th in the national bank. In social effects, the merged bank will also increase the Indonesian people's sense of trust in Islamic banks because of their strong capital and ability to compete with conventional banks.

Facing the financial integration of MEA 2020, increasing self-competence in safeguarding Islamic bank assets is important. The enlarged assets and capital of the merged bank do not rule out the possibility of expanding overseas as has been done by banks from Malaysia and Middle Eastern countries. The bank merger results need to carry out a thorough assessment of each of the human resources available to position the best talent in the right unit according to their respective abilities and expertise. Special professional certification for Islamic professional banking, which has only existed abroad, will be necessary for closeness in the country. Active collaboration between regulators, training and assessment institutions, and universities will be attractive with the potential market for sharia economists who require competency certification. Training and assessment institutions are required to conduct training and assessment with methodologies according to the National Work Competency Standards (SKKNI) (Law of the Ministry of Manpower, 2015).

Especially with Indonesia's vision to become the world's leading sharia financial and economic center, certified Islamic banking experts in Indonesia must understand the best practices of Islamic banking in the world. International banking rules, risk management regulations, corporate governance systems, accounting systems, development organizations, and financing models will adjust and adapt to international rules. As an expert for global transactions of customers who already have a cross-border business, the connected global account model is required. This global account can act as a non-state agent from an internal channel that understands other countries' economic situation as the objective of bank business expansion. Global data and information will be easily obtained due to global interactions that occur. On the other hand, Islamic economics's scientific repertoire is interesting to study in universities because of the risks and global-scale problems.

\section{CONCLUSION}

The merger of three national sharia banks, which are stateowned companies, has the right momentum and has strategic meaning to make Indonesia's vision the center of the world's sharia economy and finance. This merger step represents a choice of inorganic growth and a quantum leap for the Islamic banking industry in Indonesia. Indonesia's geostrategy such as Division in the G20 country forum, integration of MEA 2020 integration in the financial sector, Indonesia's large demographic bonus, low level of financing penetration (financing gap), low level of public financial literacy, support and commitment of the Government of Indonesia, demographics Sharia bank employees participating in the merger who are still productive, have the same enthusiasm for Islamic bank stakeholders who want to grow Islamic banks. Expertise in MSME financing (medium, small, and microfinancing) are valuable capital resources to develop the Islamic economic ecosystem. There is still room for flexibility to innovate in optimizing these resources because the banking market is not yet saturated.

The merger will generate strong Islamic bank capital, be included in the top 10 national banking rankings, and compete with other national banks. Strong capital will attract long-term resources needed by banks for business expansion. The bank merger results will be more operationally efficient, have a wider network, have a variety of products to serve the corporate, commercial, consumer, and MSME segments. Global market potential in the Islamic economic sector: halal food, Islamic finance, travel, Muslim clothing, pharmaceuticals and cosmetics, media and recreation, promising opportunities to drive the national economy during the Covid-19 pandemic. To anticipate global competition, Islamic bank human resources must have global competence and be certified.

Merger threats for BUS and other UUS. Towards 2023 there will be many spin-offs, mergers, and acquisition processes to comply with OJK regulations and strengthen national Islamic banking. Islamic economics is a different market from conventional economies because it is based on universal values and sharia principles. This inorganic growth represents a quantum leap for Indonesia's Islamic banking industry to achieve a global vision.

\section{REFERENCES}

Asian Banker. (2020, 12 6). The Largest Islamic Banks Rangking. The Asian Banker Website: https://www.theasianbanker.com/ab500/20182019/largest-islamic-banks

Bappenas. (2018). Masterplan Ekonomi Syariah Indonesia 2019 - 2024. Jakarta: Kementerian Perencanaan Pembangunan Nasional/Badan Perencanaan Pembangunan Nasional.

BI. (2012). Peraturan Bank Indonesia No.14/26/PBI/2012 tentang Kegiatan Usaha dan Jaringan Kantor Berdasarkan Modal Inti Bank. Jakarta: Bank Indonesia.

BNI. (2020, Oktober 13). Keterbukaan Informasi atau Fakta Material. PT Bank Negara Indonesia (Persero) Tbk Website:

https://www.bni.co.id/Portals/1/BNI/Perusahaan/

HubunganInvestor/Docs/penandatangananperjanjian-penggabungan-bnis-bsm-bris.pdf

BNIS. (2020, December 3). Laporan Keuangan Juni 2020. PT
Bank
BNI
Syariah
Website:

https://www.bnisyariah.co.id/Portals/1/BNISyariah/P erusahaan/Hubungan\%20Investor/laporan\%20triwula $\mathrm{n} /$ triwulanbnis2.pdf

BNIS. (2020, Oktober 21). Rancangan Penggabungan Antara PT Bank BRIsyariah Tbk, PT Bank Syariah Mandiri, dan PT Bank BNI Syariah. PT Bank BNI Syariah Website: $\quad$ https://www.bnisyariah.co.id/idid/Perusahaan/Hubungan-Investor/RingkasanRencana-Penggabungan

BPS. (2020, 12 5). Jumlah Perusahaan Menurut 2-digit KBLI (Unit), 2017-2019. Badan Pusat Statistik https://www.bps.go.id/indicator/170/447/1/jumlahperusahaan-menurut-2-digit-kbli.html

BRIS. (2020, December 3). Laporan Keuangan Juni 2020. PT Bank BRI Syariah Tbk Website: https://ir- 
brisyariah.com/misc/Laporan-Keuangan/TahunLaporan-2020/Triwulan-Juni-2020.pdf

BSM. (2020, December 3). Laporan Keuangan Juni 2020. PT Bank Syariah Mandiri Website: https://www.mandirisyariah.co.id/assets/pdf/laporanbulanan/Juni\%202020.pdf

Cartwright, S., \& Cooper, C. (1996). Managing mergers, acquisitions and strategic alliances: Integrating people and cultures. Oxford: ButterworthHeinemann.

CIMB. (2020, 12 5). One of the top banks in ASEAN. CIMB Islamic Website: https:// www.cimbislamic.com/en/who-we-are/about-us.html

Cline, M. K., \& McCaffrey, C. R. (2020). Geostrategy in Practice 2020. London: Ernst \& Young Global Limited.

DePamphilis, D. M. (2014). Mergers, Acquisitions, and Other Restructuring Activities. San Diego: Elsevier.

Dinar Standard. (2020). State of the Global Islamic Economy Report 2020/21. Dubai: DinarStandard.

DPS OJK. (2015). Roadmap Perbankan Syariah Indonesia 2015 - 2019. Jakarta: Departemen Perbankan Syariah Otoritas Jasa Keuangan.

Fatwa, N., 2017. Persaingan perbankan berdasarkan jenis bank di Indonesia. AKMEN Jurnal ilmiah, Volume 14 no 4.

Fatwa, Nur (2020) "The Development of National Islamic Foreign Exchange Bank in Indonesia," Journal of Strategic and Global Studies: Vol. 2 : No. 2 , Article 1.

Fatwa, N. 2020. Strengthening the Role of Sharia Public Banking in the Indonesian Construction Industry: Towards an Atmosphere of Sustainable Urban Development IOP Conference Series: Earth and Environmental Science 436(1),012023

Fauzan, A. (2020, November 3). Tirto. Tirto: https://tirto.id/risiko-yang-membayangi-prosesmerger-bank-syariah-pelat-merah-f6qK

Gaiduchok, O. (2019). Geoeconomic Strategies in The Modern Global Economic Space. EUREKA: Social and Humanities, 3-9.

Gates, R. M. (2020). Exercise of Power: American Failures, Successes, and a New Path Forward in the Post-Cold War World. Washington: Knopf Doubleday Publishing Group.

GIFR. (2019). Global Islamic Finance Report 2019. London: Cambridge Institute of Islamic Finance.

IFDI. (2019). Islamic Finance Islamic Development Report 2019. Jeddah: ICD - Refinitive.

IMF. (2020, 12 5). Real GDP growth: Annual percent change. International Monetary Fund Website:
https://www.imf.org/external/datamapper/NGDP_RP CH@WEO/OEMDC/ WEOWORLD/IDN

Karim, A. A. (2020). How to Strengthen Indonesian Islamic Finance to Sustain the Next Decade? Lesson Learned from 2010-2020. Jakarta: Karim Consulting Indonesia.

King, B. (2018). Bank 4.0: Banking Everywhere, Never at Bank. New York: Marshall Cavendish Business.

KNEKS. (2019). Kajian Konversi, Merger, Holding dan Pembentukan Bank BUMN Syariah. Jakarta: Komite Nasional Ekonomi dan Keuangan Syariah.

Maybank. (2020, August 28). Maybank Islamic Berhad Financial Statements: $1 H$ FY2020 ended 30 June 2020. Retrieved from Maybank Islamic Website: https:// www.maybank.com/en/investorrelations/reporting-events/reports/subsidiary-reports .page

Moin, A. (2010). Merger, Akuisisi \& Divestasi. Yogyakarta: Ekonisia.

Muchsin. (2020, Mei 6). Masyarakat Ekonomi Asean. Binus University Website: https://binus.ac.id/characterbuilding/2020/05/masyarakat-ekonomi-asean-mea/

Mulyono, H. (2017). Geostrategi Indonesia dalam Dinamika Politik Global dan Regional. Jurnal Kajian Lemhanas RI, 19-30.

Nizar, M. A. (2016). Penguatan Perbankan Syari'ah Melalui Merger atau Konsolidasi. In B. K. Indonesia, Akselerasi \& Inklusivitas Sektor Keuangan: Jalan Menuju Kesejahteraan Rakyat (pp. 121-170). Jakarta: PT Nagakusuma Media Kreatif.

OJK. (2020). Snapshot Perbankan Syariah Indonesia: Posisi Juni 2020. Jakarta: Otoritas Jasa Keuangan.

Pew Research Center. (2020, 12 5). Muslim Majorities Countries 2020. World Population Review: https://worldpopulationreview.com/countryrankings/muslim-majority-countries

Pfeffer, J. (1972). Merger as a Response to Organizational Interdependence. Administrative Science Quarterly, 382-394.

Supriyanto, E. B. (2020). Majalah Infobank. In Perspective (p. 24). Jakarta: PT Pritindo Utama.

UU Kemenaker. (2015). Keputusan Menteri Ketenagakerjaan RI No.161 Tahun 2015 tentang Penetapan Standar Kompetensi Kerja Nasional Indonesia Kategori Pendidikan Golongan Pokok Jasa Pendidikan Bidang Standardisasi, Pelatihan dan Sertifikasi. Jakarta: Menteri Ketenagakerjaan RI.

Yarger, H. R. (2006). Strategic Theory For The 21st Century: The Little Book on Big Strategy. Washington: Strategic Studies Institute U.S. 